\title{
Economic Impact
}
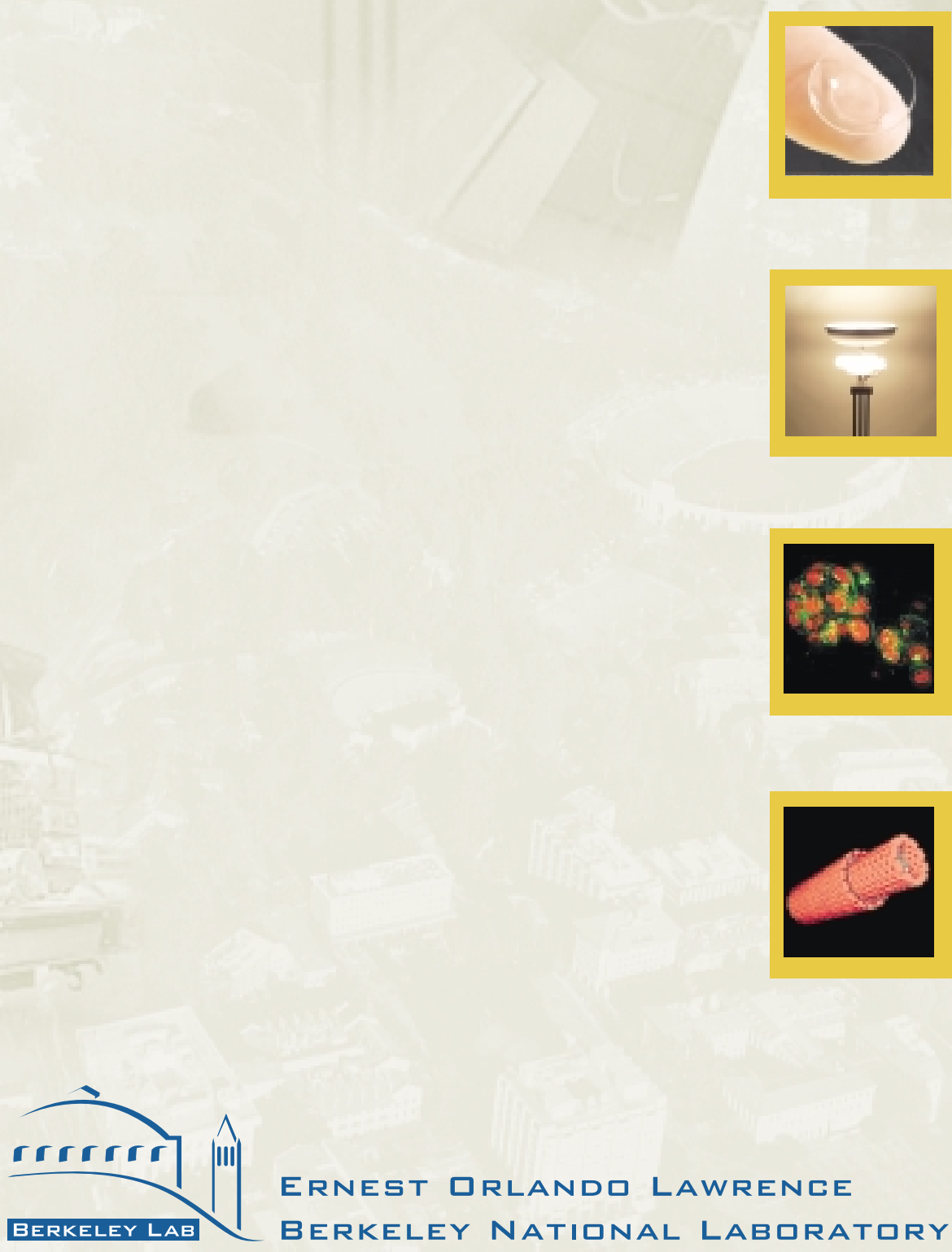

ERNEST DRLANDI LAWRENCE BERKELEY NATIONAL LABIRATIRY 


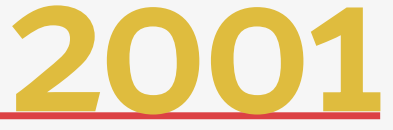

\section{Economic Impact}

Technology Transfer Department

Ernest Orlando Lawrence Berkeley National Laboratory University of California

Berkeley, CA 94720

September 2001

This work was supported by the Director, Office of Science, Office of Basic Energy Sciences, of the U.S. Department of Energy under Contract No. DE-AC03-76SFooog8.

LBNL/PUB-854

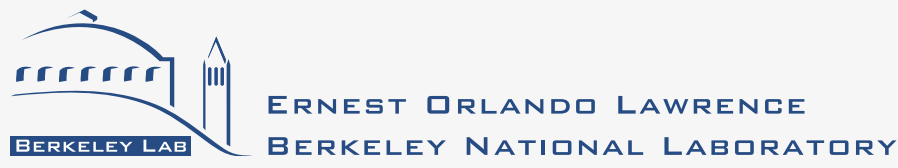




\section{ACKNOWLEDGMENTS}

This analysis was compiled by Chris Kniel, of the Technology Transfer Department, and Julie McCullough, of the Technical and Electronic Information

Department, Lawrence Berkeley National Laboratory.

The authors want to acknowledge and thank the following Berkeley Lab staff who contributed data and other information to this report: Richard Arri, Melissa Baksic, Guy Bear, Robert Berninzoni, Michael Chartock, Joe Chew, Richard Dicely, Reid Edwards, Cheryl Fragiadakis, Sharon Fujimura, Ashok Gadgil,
David Gilbert, Don Grether, Todd Hansen, Deborah Hopkins, Wes Hunt, Ron Kolb, David McGraw, James Miller, Anil Moré, Rolland Otto, Erik Page, Ron Pauer, Terry Powell, Michael Siminovitch, John Speros, William Wasson, and Vivianna Wolinsky. In addition, we wish to thank Richard Albert, Denise Allen, Marilee Bailey, Robert Couto, Theresa Duque, Dan Hawkes, Faye Jobes, Roy Kaltschmidt, Mike Muller, Flavio Robles, and Cheryl Ventimiglia of the Technical and Electronic Information Department for design, editing, photography, production, and printing. 


\section{TABLE OF CONTENTS}

I. InTRODUCTION $\ldots \ldots \ldots \ldots \ldots \ldots \ldots \ldots \ldots \ldots \ldots \ldots \ldots \ldots \ldots$

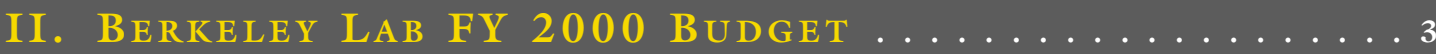

III. Employment, Salaries, And WAges ............. 4

IV. Berkeley Lab Procurement Activity FOR FY 1999 AND FY $2000 \ldots \ldots \ldots \ldots \ldots \ldots \ldots \ldots \ldots \ldots \ldots$

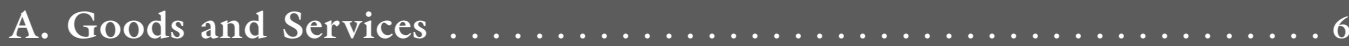

B. Leases. . . . . . . . . . . . . . . . . 6

V. Other Direct And Indirect Economic Impact . . . . 8

A. Financial Impact, Respending Effects, and Job Creation . . . . . . 8

B. National User Facilities . . . . . . . . . . . . . . 10

C. Charitable Giving $\ldots \ldots \ldots \ldots \ldots \ldots \ldots \ldots \ldots \ldots \ldots \ldots \ldots \ldots \ldots \ldots \ldots \ldots$

VI. Science and Technology Partnerships.......... 12

A. Office of Science Technology Research (SC-LTR) Program:

Transferring Research to Industry $\ldots \ldots \ldots \ldots \ldots \ldots \ldots \ldots$

B. Mechanisms to Support Partnerships $\ldots \ldots \ldots \ldots \ldots \ldots \ldots \ldots \ldots$

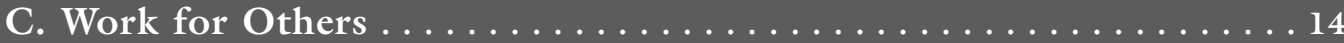

D. Patents and Licensing of Lab Technologies ............ 14

E. Impact on the Nine-County Bay Area: Partnerships and Spin-offs . . 14

F. The Bay Area Science Infrastructure Consortium (BASIC) . . . . . 14

VII. Qualitative Impact ...................

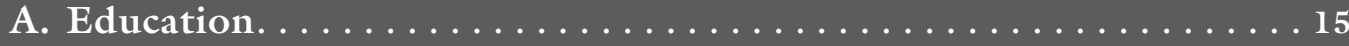

B. Berkeley Lab Firefighters: Always on Call. . . . . . . . . . 16

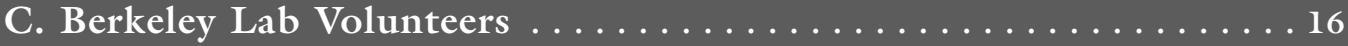




\section{I N T RO DUCTION}

\section{ERKELEY LAB HAS BEEN} part of the Bay Area community for 70 years. It has evolved from the birthplace of nuclear science and medicine into a multidisciplinary science facility that continually looks for ways to serve the public through scientific research, community participation, business and industry partnerships, and educational forums.

This laboratory is the oldest of the DOE national laboratories, and has had nine Nobel Prize winners on its research staff. It is a research leader in the fields of materials, physics, chemistry, energy, environment, computing and communications, and biology and research medicine. It is home to research centers and user facilities that provide science, services, infrastructure, and unique experimental facilities not found anywhere else in the world. Of these, four are national user facilities:

- Advanced Light Source (ALS)

- National Center for Electron Microscopy (NCEM)

- National Energy Research Scientific Computing Center (NERSC)

- 88-Inch Cyclotron

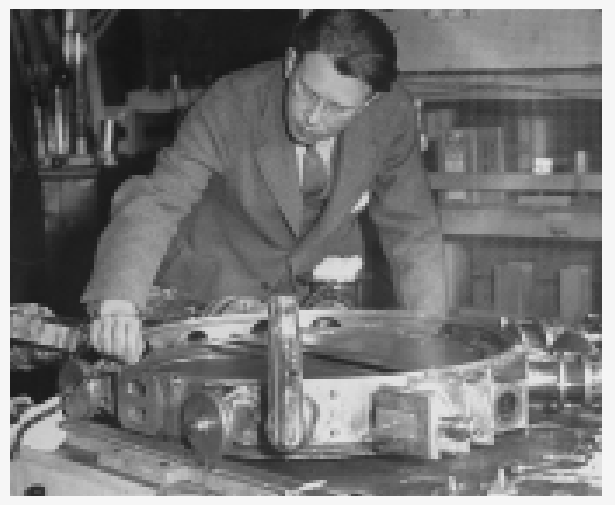

Ernest Orlando Lawrence, founder of Berkeley Lab, won the Nobel Prize for Physics in 1939 for the invention of the cyclotron.

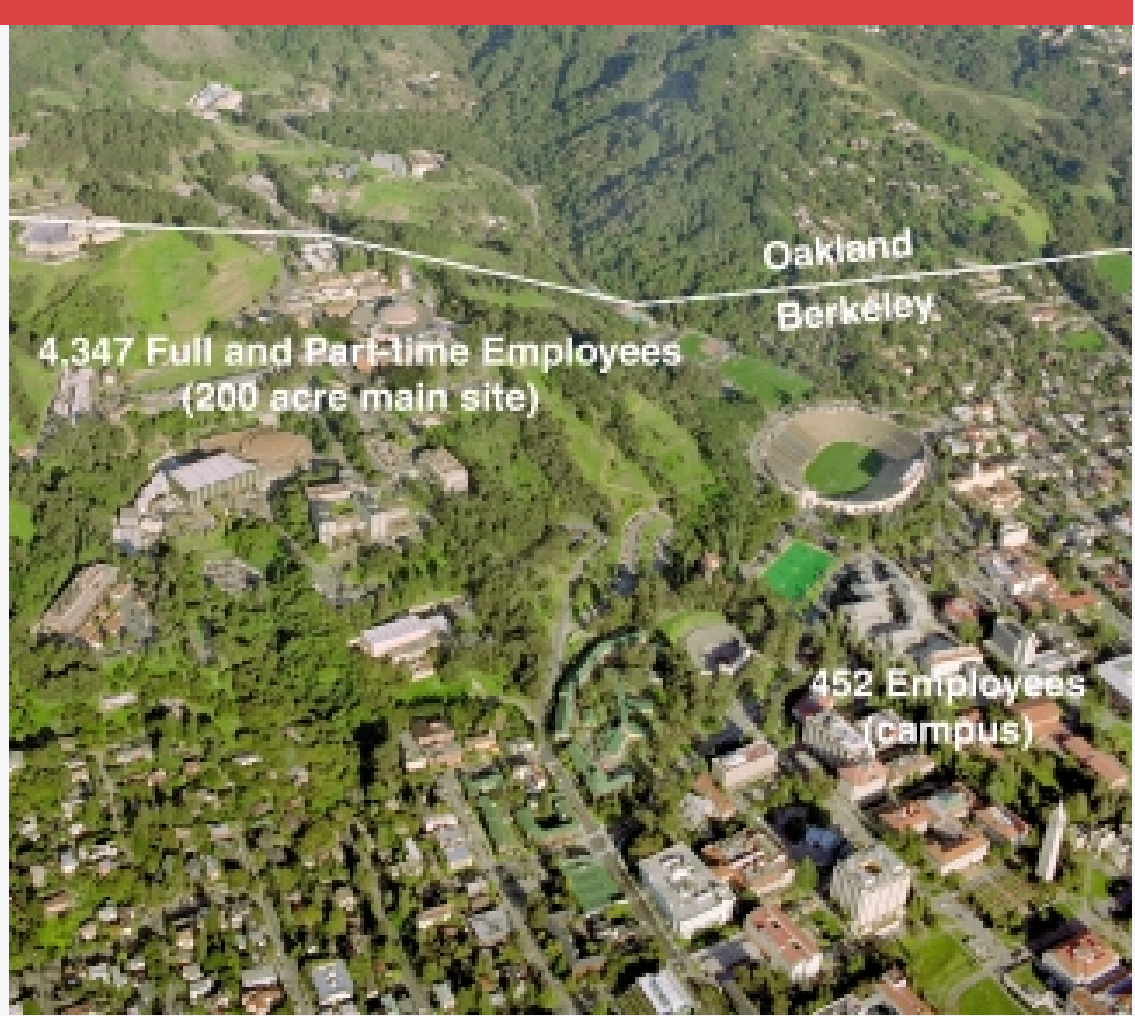

Berkeley Lab, which spans the cities of Oakland and Berkeley, has the ideal location. It is next to the University of California's Berkeley campus, and this proximity has fostered research and educational relationships for decades. Many Berkeley Lab scientists hold dual appointments at the Lab and UC Berkeley. Students from the University have always been a part of Berkeley Lab research programs, are mentored by Berkeley Lab scientists, and bring their energy, fresh approach, and new ideas to all of the Lab's research areas.

In federal fiscal year 2000 (FY00), Berkeley Lab had 4,347 full- and part-time employees. In addition, at any given time of the year, there were more than 1,000 Laboratory guests. These guests, who also reside locally, have an important economic impact on the nine-county Bay Area.

However, Berkeley Lab's total economic impact transcends the direct effects of payroll and purchasing. The direct dollars paid to the Lab's employees in the form of wages, salaries, and benefits, and payments made to contractors for goods and services, are respent by employees and contractors again and again in the local and greater economy. Further, while Berkeley Lab has a strong reputation for basic scientific research, many of the Lab's scientific discoveries and inventions have had direct application in industry, spawning new businesses and creating new opportunities for existing firms.

This analysis updates the Economic Impact Analysis done in 1996, and its purpose is to describe the economic and geographic impact of Laboratory expenditures and to provide a qualitative understanding of how Berkeley Lab impacts and supports the local community. It is intended as a guide for state, local, and national policy makers as well as local community members. Unless otherwise noted, this analysis uses data from FY00, the most recent year for which full data are available. 
Berkeley Lab scientists are constantly trying to understand the complexities of Nature, from the smallest molecular details to the infinite workings of the universe. Out of such examination, we develop technologies with practical and life-saving applications that lead to new products, such as energy-efficient lamps, a biocompatible contact lens, a portable water purifying system, and drugs to fight disease.

\section{TOOLS TO FIGHT BREAST CANCER}

For women, breast cancer is one of the most feared diseases. Each year over 180,000 American women develop the disease, and about 45,000 die from it. Chiron of Emeryville, California, is collaborating with Mina Bissell of Berkeley Lab as part of a $\$ 1.6$ million Cooperative Research and Development Agreement (CRADA) to develop new potential cancer therapies.

In 1997, Dr. Bissell, the head of the Lab's Life Sciences Division, and Valerie Weaver, a post-doctoral scholar in cell and molecular biology, demonstrated that what is happening outside a cell can be equally if not more important than the presence of cancerous genes. This particular experiment was an articulation of over 15 years of research. Bissell theorized in 1982 that there is an important link between the development of breast cancer and a network of fibrous proteins surrounding breast cells called the "extracellular matrix," or ECM. Bissell and her colleagues have shown that the ECM is crucial to the normal functioning of cells, and loss of or damage to the ECM can lead to malignancy in transgenic mice. (To find out more, see http://www.lbl.gov/lifesciences/BissellLab/main.html.)
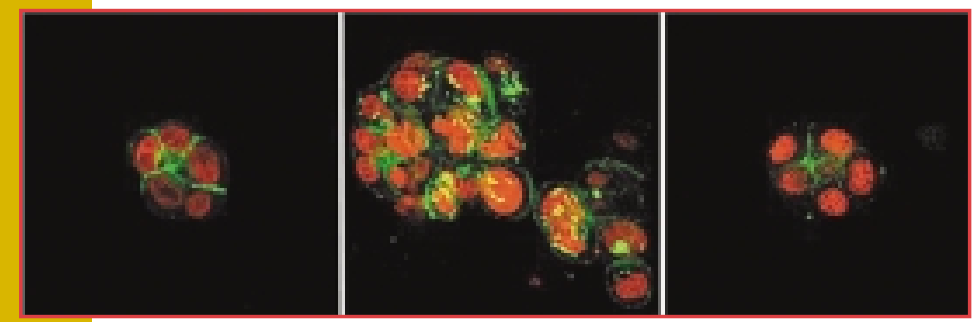

A cluster of normal breast cells (left), tumor cells (center), and reverted tumor cells (right). Berkeley Lab and Chiron, Inc., are presently using a novel tumor cell reversion model to test nearly a million compounds and find potential lead drugs for novel anticancer therapies.

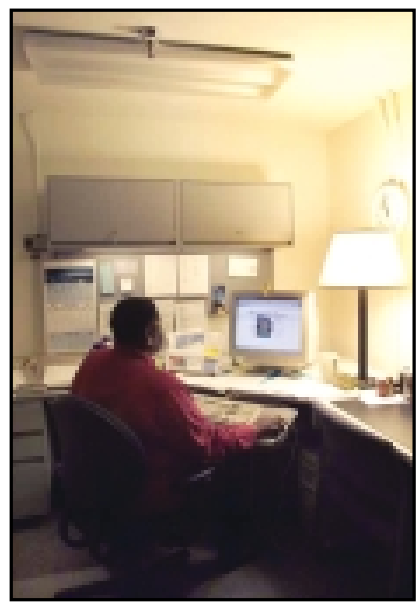

THE BERKELEY LAMP HELPS TO KEEP THE LIGHTS ON

This lighting system consists of two compact fluorescent lights, separated by an optical septum allowing for either ambient or task light. Coming at a time when California is experiencing power alerts and facing energy shortages, this lighting system can match the performance of a 300-watt torchière and a 150watt incandescent lamp using

$25 \%$ of the energy. According to Michael Siminovitch of the Lab's Lighting Systems Research Group, who with Erik Page invented the system, "nothing currently available in the office, hospitality, or residential marketplace has, to our knowledge, both the highperformance lighting quality characteristics and energy efficiency of this new lamp." (To find out more, see http://lighting.lbl.gov/projects/table/table.html.)

The Berkeley Lamp is being tested by the Sacramento Municipal Utility District, Southern California Edison, and Pacific Gas and Electric. It is available for purchase in stores and on-line at http://www.lightcorp.com/.

\section{UV WATERWORKS: PURIFYING WATER AND SAVING LIVES AROUND THE WORLD}

Berkeley Lab and WaterHealth, International, have created and marketed an effective, portable, easy-to-use, inexpensive ultraviolet disinfection system. UV Waterworks kills the viruses and bacteria that cause cholera, typhoid, dysentery, and other deadly diseases. In 1998, the system was successfully used in the Caribbean after Hurricane Mitch left thousands without drinking water.

The technology is being expanded to include a combination of physical filtration, chemical filtration, and UV disinfection. Known as the Emergency Relief Unit, this new system can effectively treat water contaminated with turbidity, bacteria, viruses, protozoan cysts, organic chemicals, heavy metals, and nitrates. (To find out more, see http://eetd.lbl.gov/cbs/archive/uv/.)

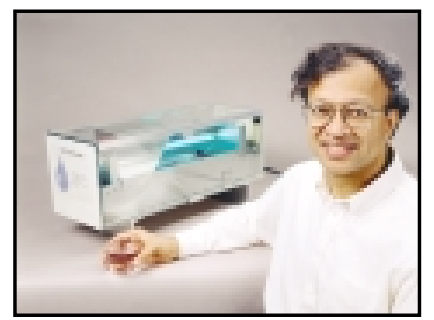

"Unlike other ultraviolet-based water purifiers, UV Waterworks does not require pressurized water-delivery systems and electrical outlets and is highly

suitable for remote locations and emergency response situations," stated Berkeley Lab scientist Ashok Gadgil, inventor of the device. 


\section{I BERKELEY LAB FY 2000 BUdGeT}

ERKELEY LAB IS ONE OF the largest businesses in Alameda County. The FY 2000 (October 1, 1999, through September 30, 2000) Lab budget was $\$ 405$ million. Purchases in the Bay Area alone for FY 2000 topped \$89 million.

However, what cannot be completely captured is the large financial impact the Lab has through the fact that its employees and their families live in Bay Area communities, shop in Bay Area stores, and participate in Bay Area schools. Berkeley Lab is an integral part of the nine-county Bay Area community.

Berkeley Lab is primarily funded by the U.S. Department of Energy (DOE) and is one of 16 DOE national laboratories. Of the Lab's FY00 \$405 million budget, DOE provided $\$ 274$ million of the Lab's operating budget and another $\$ 62$ million in construction and equipment funding. Altogether, DOE accounted for $83 \%$ of the Lab's revenue in FY00. The other major source of funding was the National Institutes of Health (NIH) at \$21 million (or $5 \%$ of total Berkeley Lab revenue). The remaining $\$ 51$ million (or 11\%) of Berkeley Lab funding was provided from various other government and industry sources.

\section{FY 2000 Laboratory Budget \$405 M by Funding Source}

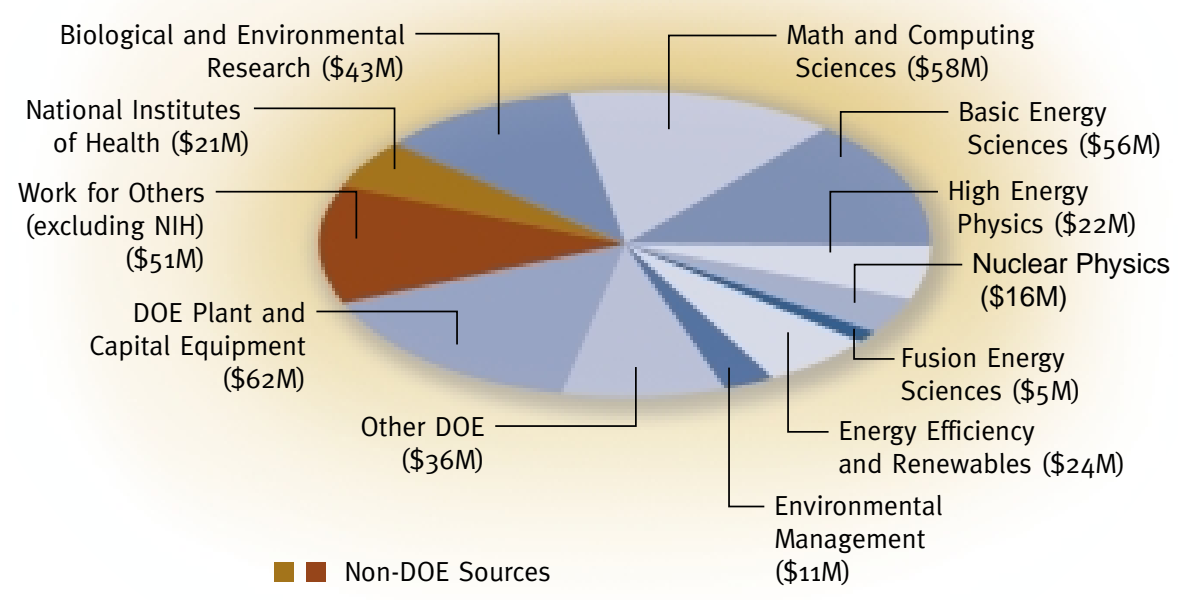

Total Laboratory Budget in Millions:

FY 1996-FY 2000

\$Millions

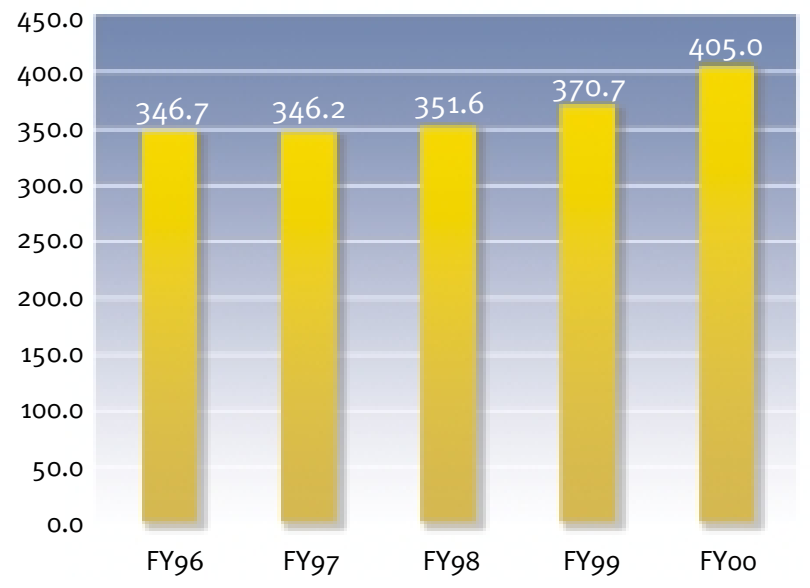




\section{I - Employment, Salaries, AND Wages}

S Of August 31, 2000 , Berkeley Lab had employed an annual workforce of 3,123 full-time and 1,224 part-time individuals, a total of 4,347 employees. In addition, at any given time during the fiscal year, the Lab played host to over 1,000 guests, who temporarily reside in the Bay Area.

Most Berkeley Lab employees live in the East Bay, with over 2,700 (63\%) in Alameda County and over 1,000 (30\%) in Contra Costa County; 1,685 (35\%) Lab workers live in Berkeley, and $490(11 \%)$ live in Oakland (both part of Alameda County).

\section{Employees by County}

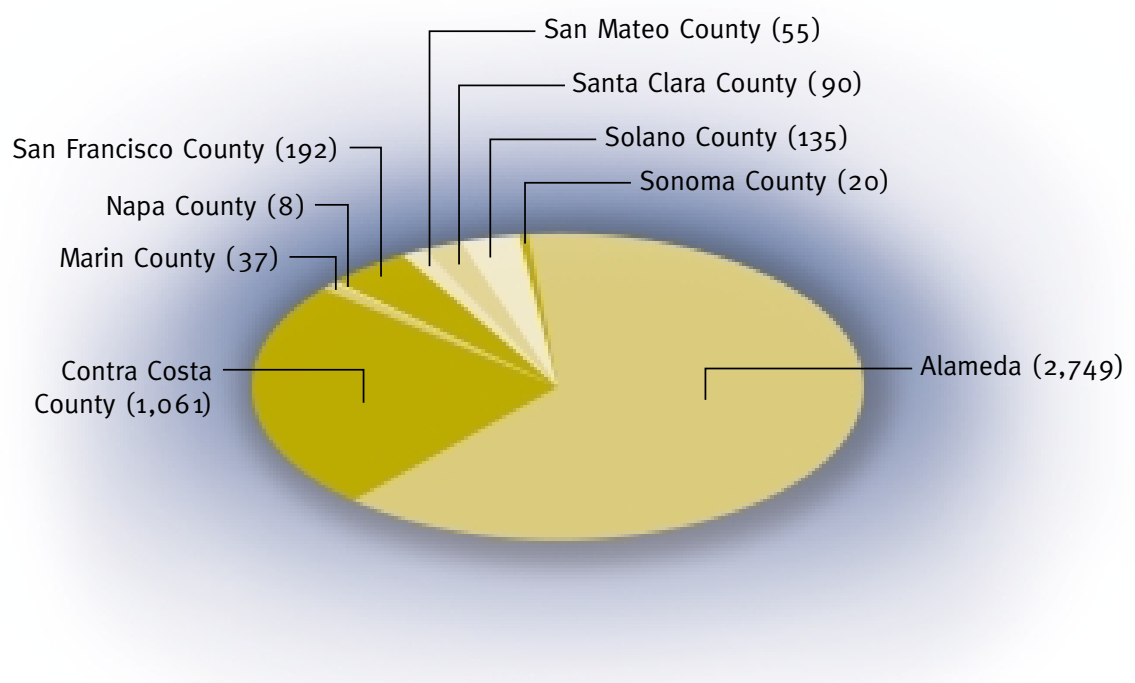

ANNUAL FULL- AND PART-TIME LAB WORKFORCE IN THE BAY AREA AS OF $8 / 31 / 00$

\section{BAY AREA COUNTY}

NO. OF LAB EMPLOYEES RESIDING IN COUNTY

\begin{tabular}{lr} 
Alameda County & 2,749 \\
Contra Costa County & 1,061 \\
\hline Marin County & 37 \\
Napa County & 8 \\
San Francisco County & 192 \\
San Mateo County & 55 \\
Santa Clara County & 90 \\
Solano County & 135 \\
Sonoma County & 20
\end{tabular}

Total Full-Time and Part-Time Lab Employees in the Bay Area $4,347^{*}$

*In addition to the above, in FY00 more than 1,000 guests were working at the Lab and living in the Bay Area at any given time. 
FIFTEEN LARGEST EMPLOYERS IN THE BAY AREA (FY 2000)

\section{COMPANY}

BAY AREA EMPLOYEES

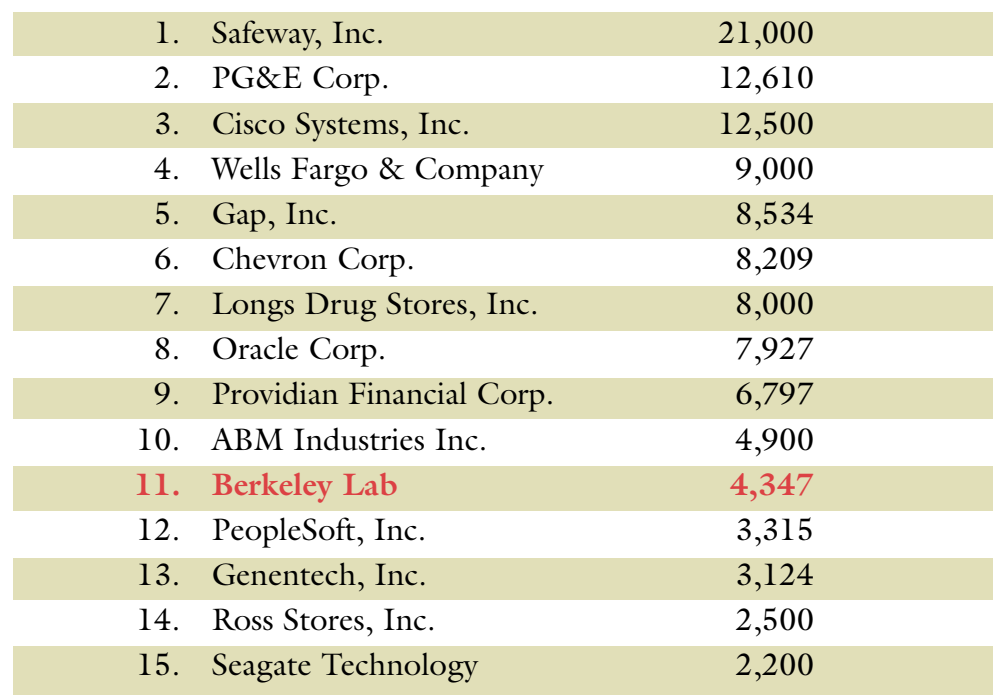

Source: Adapted from Chronicle 500 Charts, 50 Largest Bay Area Employers, March 2001.
During FY 2000, the Lab spent approximately $\$ 186$ million in salaries and wages. Of this amount, $\$ 55$ million went to employees living in Berkeley, with a total of $\$ 118$ million paid to Alameda County residents. Berkeley Lab is the second largest employer in Berkeley.

Employees from Contra Costa County earned \$45 million. Altogether, Berkeley Lab directed $\$ 163$ million of its salary and wage payments to employees living in the East Bay.

Compared with Bay Area corporations, Berkeley Lab ranks as one of the 15 largest employers. 


\section{Berkeley Lab Procurement Activity for Fy 1999 and Fy 2000}

\section{A. Goods and Services}

uring FY 2000, the Lab purchased \$196.5 million in goods and services. Of this amount, \$69 million, or 35\%, went to small businesses.

Total purchases in FY99 for the nine-county Bay Area from small businesses was \$36.9 million. Total purchases for FY00 were $\$ 42.2$, a nearly $15 \%$ increase.

\section{B. Leases}

One subset of goods and services purchased by Berkeley Lab is property leases for satellite offices. Presently, the Laboratory rents seven properties, four in Berkeley, one in Oakland, one in Walnut Creek, and one in Washington D.C. The five local Berkeley and Oakland leases are shown below.
Altogether, Berkeley Lab expends over $\$ 185,000$ monthly on property leases in the city of Berkeley, or $\$ 2.2$ million per year.

\section{BERKELEY AND OAKLAND LEASES}

Building 903 (Warehouse)

270 Seventh Street, Berkeley, CA

Building 933 (The Berkeleyan)

Building 937 (Berkeley Tower) 1950 Oxford Street, Berkeley, CA

Building 941 (Berkeley Center Bldg.) 2120 University Ave., Berkeley, CA 2000 Center St., Berkeley, CA

\section{TOTAL BERKELEY LAB PURCHASES: ALL BUSINESSES AND NONCOMMERCIAL ENTITIES}

FOR ALL LOCATIONS

FY 1999

$\$ 189,873,000$

13,281

3,324

FY 2000

Total Value Goods and Services

Total No. Vendors/Suppliers

Total No. Purchase Orders
$\$ 196,458,000$

2,780

11,434

TOP 5 VENDORS/SUPPLIERS

GE Capital Corporation/Potomac

IBM Corporation

Sprint Communications Company

Allied Signal Inc.

$\$ 27,941,000$
$\$ 10,932,000$
$\$ 10,481,000$
$\$ 7,807,000$
$\$ 7,066,000$

Qwest Communications Int'l

Regents of the University of California

$\$ 25,077,000$

Amersham Pharmacia Biotech Inc

$\$ 7,209,000$

Encinal Broadway LLC

$\$ 6,143,000$

Castlerock LP 
2. PURCHASES FROM SMALL BUSINESSES: ALL LOCATIONS

FY 1999

FY 2000

Total Value Goods and Services

$\$ 88,638,000$

$\$ 69,145,000$

Total No. Vendors/Suppliers

2,343

1,961

Total No. Purchase Orders

8,837

7,783

TOP 5 VENDORS / SUPPLIERS - \$ COMMITMENTS

Castlerock LP

GC Micro Hardware \& Software

Micromass

James R. Griffin, Inc.

Hoop Communications, Inc.

$\$ 5,931,000$
$\$ 4,505,000$
$\$ 880,000$
$\$ 710,000$
$\$ 682,000$

Encinal Broadway LLC

Castlerock LP

GSE Construction

Wang NMR Inc

Martinez \& Turek
$\$ 6,143,000$

$\$ 4,442,000$

$\$ 4,400,000$

$\$ 1,908,000$

$\$ 1,469,000$

\section{PURCHASES FROM BAY AREA: ALL BUSINESSES AND NONCOMMERCIAL ENTITIES}

FY 1999

$\$ 70,621,000$

1,355

6,802
FY 2000

$\$ 89,490,000$

1,186

6,847

Total Purchase Orders

TOP 5 VENDORS / SUPPLIERS - \$ COMMITMENTS

$\begin{array}{llll}\text { Castlerock LP } & \$ 5,931,000 & \text { Encinal Broadway LLC } & \$ 6,143,000 \\ \text { PE Biosystems } & \$ 5,887,000 & \text { Castlerock LP } & \$ 4,442,000 \\ \text { GC Micro Hardware \& Software } & \$ 4,505,000 & \text { GSE Construction } & \$ 4,400,000 \\ \text { Sun Microsystems, Inc. } & \$ 2,043,000 & \text { On-Site Engineering \& Management, Inc. } & \$ 3,829,000 \\ \text { Contra Costa Electric, Inc. } & \$ 1,989,000 & \text { NV Heathorn, Inc. } & \$ 3,386,000\end{array}$

\section{PURCHASES FROM BAY AREA SMALL BUSINESSES}

\begin{tabular}{|c|c|c|c|}
\hline & FY 1999 & & FY 2000 \\
\hline Total Value Goods and Services & $\$ 36,877,000$ & & $\$ 42,206,000$ \\
\hline Total No. Vendors/Suppliers & 1,030 & & 894 \\
\hline Total No. Purchase Orders & 5,262 & & 5,313 \\
\hline Castlerock LP & $\$ 5,931,000$ & Encinal Broadway LLC & $\$ 6,143,000$ \\
\hline GC Micro Hardware \& Software & $\$ 4,505,000$ & Castlerock LP & $\$ 4,442,000$ \\
\hline James R. Griffin, Inc. & $\$ 710,000$ & GSE Construction & $\$ 4,400,000$ \\
\hline Hoop Communications, Inc. & $\$ 682,000$ & Wang NMR, Inc. & $\$ 1,908,000$ \\
\hline Goebel Paving Grading & $\$ 605,000$ & Oxford Instruments & $\$ 1,099,000$ \\
\hline
\end{tabular}




\section{OThER Direct AND INDIRECT ECONOMIC IMPACT}

\section{A. Financial Impact, Respending Effects, and Job Creation}

key value of Berkeley Lab stems from its role in facilitating the discovery and transmission of knowledge for society at large. Much of this report provides the reader with a perspective and specific background on the many ways that the Lab provides these societal benefits. However, to the surrounding Bay Area, the Laboratory also acts as a large employer and consumer of goods and services, and its economic impact on the local community is quite significant. Dollars expended by Berkeley Lab do not stop creating economic opportunities upon payment to a Lab employee or contractor. This money is respent again and again in the economy, creating jobs and income for businesses and other workers. Many individuals not employed by the Laboratory and numerous businesses depend to some extent upon the ripple effects of Berkeley Lab spending for their livelihoods.

\section{Direct Impact}

Direct spending in the Bay Area attributable to Berkeley Lab's (LBNL) presence is estimated to be $\$ 385$ million, consisting of the following:

\section{Indirect Impact}

Berkeley Lab's indirect economic impact is determined by applying a multiplier to Total Direct Expenditures. The multiplier measures the secondary income and employment generated by the Lab's initial direct spending. The multiplier concept recognizes that spending initiates an economic chain reaction of further spending, produc- tion, income, and employment. Similar studies indicate that a multiplier of 0.49 approximates the indirect spending impact and a multiplier of 0.62 approximates the additional jobs created by Berkeley Lab's direct expenditures. Based on the application of these multipliers, Berkeley Lab is responsible for:
Indirect spending in the Bay Area Indirect creation of additional jobs in the Bay Area $(4,347$ employees * 0.62$)$

$\$ 189 \mathrm{M}$

(4,

\section{Combined Direct and Indirect Impact}

In summary, for FY00 Berkeley Lab's total direct and indirect economic impact and its contribution to Bay Area employment are estimated as follows:

\begin{tabular}{|lr|}
\hline Total Direct Expenditures & $\$ 385 \mathrm{M}$ \\
\hline Indirect Spending in the Bay Area & $\$ 189 \mathrm{M}$ \\
\hline Total Financial Impact & $\$ 574 \mathrm{M}$ \\
\hline Lab Employees in Bay Area (FT and PT) & 4,347 Employees \\
Indirect Creation of Add'l. Jobs in Bay Area & 2,700 Add'l. Jobs \\
\hline Total Job Creation & 7,047 Jobs \\
\hline
\end{tabular}

\begin{tabular}{|lr|}
\hline Berkeley Lab Expenditures on Goods and Services & $\$ 89 \mathrm{M}$ \\
Expenditures of LBNL's Faculty and Staff & $\$ 170 \mathrm{M}$ \\
Employee and Retiree Benefits & $\$ 55 \mathrm{M}$ \\
Expenditures of Guests & $\$ 51 \mathrm{M}$ \\
Conferences & $\$ 20 \mathrm{M}$ \\
\hline Total Direct Expenditures & $\$ 385 \mathrm{M}$ \\
\hline
\end{tabular}




\section{UP CLOSE AND FAR AWAY}

Scientists have vision. They see possibilities where many people only see confusing images under a microscope or far-away dots in the sky. They see not only what a thing is, but what it can and could do: cure a disease, make a new energy source, feed the hungry, answer the questions we all have about who we are and where we came from.

A number of scientists are using their vision, and the tools of the ALS user facility, to examine ribosome crystals and determine how proteins are made. Ribosomes live in the cytoplasm of the cells of all living creatures and transcribe the genetic code into proteins. By studying the image of their atomic structure, we can begin to understand how these molecules furnish the machinery and controls for cellular functions.

In the cell, the ribosome attaches to strands of messenger RNA (mRNA), which are copies of a gene sequence of DNA. As they travel along these strands, transfer RNA (tRNA) within the ribosome "reads" the genetic coding and uses the data to assemble a specific amino acid and attach it to a growing strand of protein, which gradually emerges from a channel in the ribosome.

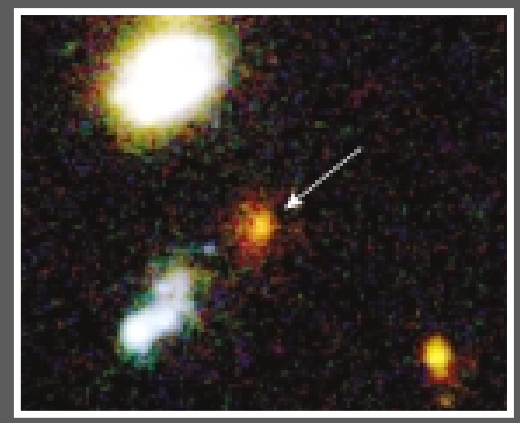

Drs. Marat M.

Yusupov and Harry Noller of UC Santa Cruz recently led a team of scientists who used the ALS facility to look at crystals of the evolutionarily conserved $70 \mathrm{~S}$

ribosome of the bacterium Thermus thermophilus at a resolution of 5.5 angstroms (ten billionths of a meter). This ribosome is a good candidate for study as it shares many characteristics with its human counterpart.

At this resolution, researchers were able to incorporate tRNA and mRNA in their crystals, more clearly seeing how transfer RNA interacts with the ribosome and how its two subunits interact with one another, and determining for the first time the structure of a complete ribosome. (To find out more, visit http://www.lbl.gov/ScienceArticles/Research-Review/Highlights/ 2000/stories/bioscience/ribosomal. html.)

Other scientists at Berkeley Lab have turned their vision to the stars to look at ancient and far-away objects. Highspeed computer modeling at NERSC made it possible for Berkeley Lab and the Space Telescope Science Institute to analyze data from an exploding star caught by NASA's Hubble Space Telescope. The supernova, named SN $1997 \mathrm{ff}$, is considered the oldest and most distant Type 1a supernova ever seen, coming in at over 10 billion

By examining SN $1997 \mathrm{ff}$ and other

distant supernovae, we learned

that we live in an accelerating universe.
Seeing the ribosome in action. This image of the different molecular components of a ribosome was taken at the Berkeley Center for Structural Biology, headed by Dr. Thomas N. Earnest and located at the ALS.

Bound tRNAs (yellow, red, orange), ribosomal RNAs (cyan, gray, and light purple), and the two main protein subunits of the ribosome: 305 (dark purple) and 505 (medium purple).

years old, and supports the cosmological model of an accelerating universe.

Berkeley Lab astrophysicist Peter Nugent, a member of the team led by Adam Riess at the Space Telescope Science Institute that studied the distant supernova, used an IBM SP supercomputer to perform the analysis at NERSC, the world's largest unclassified supercomputing center. (To find out more, visit http://www.lbl.gov/ Computing-Sciences/Archive/ headlines04-02-01.html). 


\section{B. National User Facilities}

Berkeley Lab has developed and maintains four designated national user facilities on site: the Advanced Light Source, the National Energy Research Scientific Computing Center, the National Center for Electron Microscopy, and the 88Inch Cyclotron.

These unique facilities are available for use by scientists from other universities, as well as industry and government institutions, and over the past few years they have made possible some dramatic scientific break- throughs. Within the last two years, discoveries involving Berkeley Lab national facilities and scientists have spanned the extremes in the natural world. Using the ALS, a team of researchers has produced high-resolution (7.7 and 5.5 angstrom) images of a complete ribosome complex. With the tools of the NERSC supercomputer facility, Berkeley Lab scientists have also been part of the discovery of the most distant, and hence oldest, Type la supernova ever found.

\section{Charitable Giving}

Each year, employees participate in the Berkeley Lab SHARES (Science for Health, Assistance, Resources, Education and Services) campaign. Through SHARES, the Lab works with four organizations-United Way of the Bay Area, Earth Share of California, Community Health Charities, and the Bay Area Black United Fund.
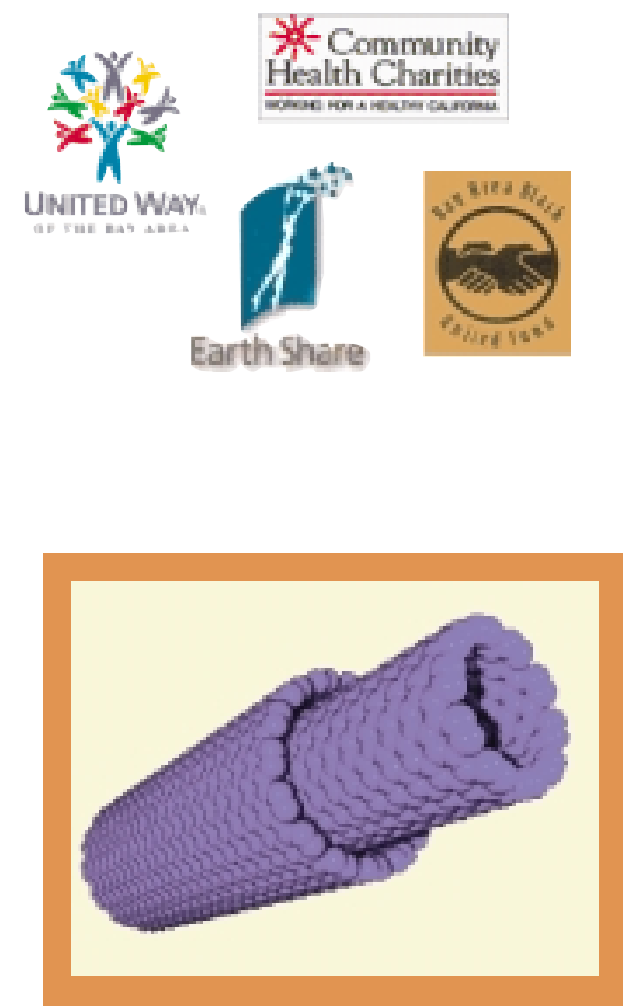

Multiwalled carbon nanotubes.

Alex Zettl, of Berkeley Lab's Materials Sciences Division, and John Cumings, UCB physics graduate student, used the National Center for Electron Microscopy's advanced instruments to carefully remove the capped end of a nanotube and extrude from it a smaller nanotube. Much, says Zettl, "like the telescoping of a mariner's traditional spyglass." 


\section{SC-LTR INDUSTRY PARTNER SURVEY}

In late 1997 and early 1998, the national laboratories surveyed their industry partners to identify strengths and weaknesses of the SC-LTR partnership program. A survey questionnaire was sent to approximately 300 previous and existing industry partners of four multiprogram Energy Research Laboratories-Brookhaven, Berkeley, Oak Ridge, and Pacific Northwest. Of these, 126 companies responded.

The responses overwhelmingly indicate that, despite the fact that no government funds are provided to the companies, industry strongly supports the research partnership with national laboratories and has benefited from the program.

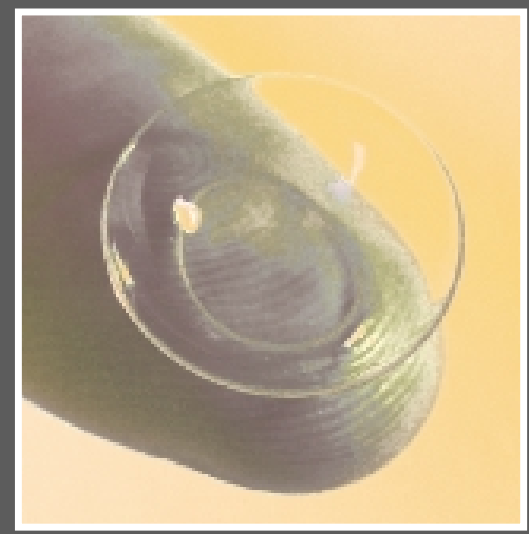

\section{What our industry partners say about the benefits of working with Berkeley Lab:}

"Local access to technology we couldn't afford to install."

$$
\text { - Chiron }
$$

"The ability to access a substantial and dependable science base." - Western Atlas, Inc.

"High input at the level of innovation; high vision on emerging technologies.”

\section{- Rhone Poulenc Rorer}

"The greatest single benefit from the partnership is to understand more of the fundamentals behind the facts."

- Sunsoft Corp.

\section{BIOCOMPATIBLE CONTACT LENSES: PUT THEM IN, FORGET ABOUT THEM, AND GO!}

Operating under a CRADA between Berkeley Lab and Sunsoft Corporation (recently acquired by Ocular Sciences of Concord, CA), a research team led by Carolyn Bertozzi of the Materials Sciences Division has developed two new biocompatible materials for contact lenses. The first is a coating that will decrease protein binding (reducing the growth of bacteria) and increase water binding to the surface of the contact lens (allowing for necessary oxygen flow). The second is a contact lens design that resembles the carbohydrate-coated surface of a human cell. (To find out more, visit http:// www.lbl.gov/Science-Articles/ResearchReview/Highlights/200o/stories/health/ soft_touch.html.) 


\section{SCIENCE AND TEChNOLOgY PARTNERSHips}

B USINESS AND INDUSTRY build on Berkeley Lab research. On average, the Lab produces approximately 100 new inventions each year, many with commercial value and many available for licensing. The Laboratory has the resources, expertise, and team infrastructure to make commercial and industrial R\&D efforts cost effective and, given our track record, successful. Partnerships with Berkeley Lab allow companies to bring goods, services, and medical treatments to market much sooner.

Transfer of Berkeley Lab technologies to the world at large depends on communication between the people generating the knowledge and the
The SC LTR Tech Transfer Partnership Program is one of a few programs focused on bridging the Basic-Applied Gap

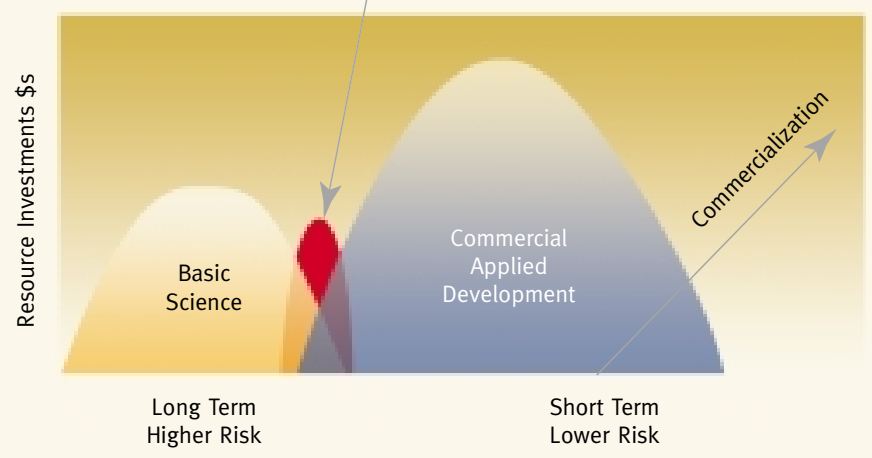

Cycle Life

Getting the technology out of the Lab and into the industry sector is managed by Technology Transfer.

\section{BERKELEY LAB / INDUSTRY PARTNERSHIPS}

\begin{tabular}{|c|c|}
\hline Applied Materials, Inc., Santa Clara & Particle-Free Wafer Processing \\
\hline Catalytica, Inc., Mountain View & $\begin{array}{l}\text { Optimized Catalysts for the Cracking of Heavier Petroleum } \\
\text { Feedstocks Initial Experiments }\end{array}$ \\
\hline Cell Genesys (was Somatix Therapy Corp.), Foster City & Neurochemical Imaging of Gene Therapy \\
\hline Chiron Corporation, Emeryville & Structure Determination of M-CSF and its Variants \\
\hline Coulter Pharmaceuticals, Palo Alto & $\begin{array}{l}\text { Development of Novel Biological Targeted Therapies for ErbB2 } \\
\text { Oncogene Products }\end{array}$ \\
\hline Empire Magnetics, Inc., Rohnert Park & High Performance Micro Stepping Motor \\
\hline $\begin{array}{l}\text { General Nanotechnology, Div. of Technical Instruments } \\
\text { Corp., San Francisco }\end{array}$ & Diamond Tipped Probes for Atomic Force Microscopy \\
\hline Hewlett-Packard Laboratories, Palo Alto & Light Emission Processes and Dopants in Solid State Light Sources \\
\hline Hewlett-Packard Laboratories, Palo Alto & Blue-Emitting GaN LEDs and Lasers \\
\hline IBM, San Jose & Facility for Studying Micromagnetic Structures \\
\hline Kaiser Foundation Hospital, Oakland & $\begin{array}{l}\text { National Information Infrastructure (NII) Prototype for } \\
\text { Distributed Health Care Imaging }\end{array}$ \\
\hline Optical Coating Laboratory, Inc., Santa Rosa & Electrochromic Window Product Development \\
\hline Oryx Instruments \& Materials Corporation, Fremont & $\begin{array}{l}\text { Transfer of an X-ray Interference Fringe Refinement } \\
\text { Software Package }\end{array}$ \\
\hline Rhone-Poulenc Rorer, Santa Clara & Cloning Genes for Atherosclerosis and Respiratory Therapeutics \\
\hline Roche Bioscience, Inflammatory Diseases Unit, Palo Alto & $\begin{array}{l}\text { A Transgenic Approach to the Development of Novel Model } \\
\text { Systems to Combat Asthma }\end{array}$ \\
\hline Seagate Recording Media, Fremont & $\begin{array}{l}\text { Raman Spectroscopy Characterization of Amorphous Carbon } \\
\text { Coatings for Computer Hard Disks }\end{array}$ \\
\hline Spectrum Sciences, Santa Clara & Ion Beam Experiment \\
\hline WaterHealth International, Napa & UV Disinfection of Drinking Water \\
\hline
\end{tabular}


people who can use it. The Lab's Technology Transfer Department is the intermediary between Berkeley Lab research programs and private industry.

\section{A. The Office of Science} and Technology (SC-LTR) Program: Transferring Research to Industry

The SC-LTR Program is a part of Berkeley Lab's Tech Transfer Department and supports the DOE's overall technology transfer program. Its mandate is to enhance U.S. industrial competitiveness through collaborations between national energy research laboratories and industry.
These collaborative research projects are cost-shared partnerships. The SCLTR Program funds only the national laboratory's research, while the industry partner supports its research and often provides additional equipment, funds, or supplies to the laboratory. Thus, a laboratory and its industrial partners can explore scientific and technical approaches that would be too risky or resource constrained for either to undertake alone.

\section{B. Mechanisms to Support Partnerships}

Companies can contact Tech Transfer and choose from a number of different working partnerships with Berkeley Lab.
- To get initial or background information on Lab activities and capabilities, a company can arrange for an information exchange. Tech Transfer sends out publications or sets up electronic presentations, briefings, workshops, and meetings with Berkeley Lab scientists.

- A small business can get technical assistance from the Lab to solve unique problems. This is short-term support targeting specific areas. Typically, the company covers any travel expenses.

- Sometimes a company or university needs a specialized facility or equipment, such as the Lab's Advanced Light Source. In this case, the partner can enter into a User Facility Agreement with Berkeley Lab.

\begin{tabular}{|c|c|c|}
\hline COMPANY & BUSINESS & YEAR \\
\hline Covalent Materials, Inc. & Nanotechnology & 2001 \\
\hline Cargo Technology, Inc. & Gas-filled panel insulated shipping containers. & 2000 \\
\hline Xradia, Inc. & Nanofabrication of X-ray imaging technologies. & 2000 \\
\hline Syrrx, Inc. & $\begin{array}{l}\text { Structural proteomics (the process of generating } \\
\text { protein from genetic information) for drug discovery. }\end{array}$ & 1999 \\
\hline Ariel Technologies, Inc. & Scanning tip microwave near-field microscopes. & 1998 \\
\hline Quantum Dot Corporation & $\begin{array}{l}\text { Nanometer-sized fluorescent probes, which can label } \\
\text { and measure biological systems, such as living cells. }\end{array}$ & 1998 \\
\hline Aeroseal, Inc. & $\begin{array}{l}\text { A quick, inexpensive, aerosol-based duct-sealing } \\
\text { system to reduce heating and cooling energy } \\
\text { use. }\end{array}$ & 1997 \\
\hline $\begin{array}{l}\text { Neomorphic Software, Inc. } \\
\text { (Acquired by Affymetrix 10/30/00) }\end{array}$ & $\begin{array}{l}\text { Genomic data analysis. Neural network software to } \\
\text { predict DNA regulatory sites. }\end{array}$ & 1997 \\
\hline Berkeley HeartLab, Inc. & $\begin{array}{l}\text { Advanced blood cholesterol testing for diagnosis and } \\
\text { treatment of heart disease. }\end{array}$ & 1997 \\
\hline Data Logic Division of Gene Logic Corp. & $\begin{array}{l}\text { A tool used facilitate the management of complex } \\
\text { scientific databases. }\end{array}$ & 1997 \\
\hline WaterHealth International & Portable low-power water disinfection units. & 1996 \\
\hline Symyx Technologies, Inc. & $\begin{array}{l}\text { Technology to rapidly and cost-effectively discover materials } \\
\text { such as catalysts, polymers, and electronic materials. }\end{array}$ & 1994 \\
\hline Cutting Edge Products, Inc. & Ion deposition for tool hardening. & 1991 \\
\hline Morris Research, Inc. & High Tc superconductivity instrumentation. & 1990 \\
\hline PolyPlus Battery Company & $\begin{array}{l}\text { Environmentally friendly, high power-density, } \\
\text { lithium polymer battery. }\end{array}$ & 1990 \\
\hline
\end{tabular}


- When Berkeley Lab, the U.S.

Department of Energy, and a company have a mutual interest in developing a technology (and cost sharing among them can be agreed), these groups can enter into a Cooperative Research and Development Agreement (CRADA).

- When a company wants a high degree of control over the work, it can conduct sponsored research at the Lab (Work for Others). In such a case, the company fully funds the research. The Lab provides the facility and the researchers.

- When Berkeley Lab has the rights to a technology or software that fits a company's technical needs and business strategy, they can negotiate a licensing agreement. In this case, Berkeley Lab transfers the rights to use patented inventions or copyrighted software to the licensing company.

\section{Work for Others}

Work for Others consists of sponsored research and development projects and technical assistance efforts that are fully funded by private industry or non-DOE government agencies. This work must use a unique capability of Berkeley Lab and not place it in competition with the private sector. The Lab annually receives in excess of $\$ 40$ million in sponsored research funding from non-DOE sponsors such as the National Institutes of Health, Amgen, Children's Hospital, the U.S. Navy, and other entities.

\section{Patents and Licensing of Lab Technologies}

Berkeley Lab seeks to license its intellectual property to promote commercialization of its inventions, both for application by industry and to promote the research and technology transfer interests of the Lab and its research staff. In FY 2000, the Lab filed 33 U.S. patent applications, 35 patents were issued, and private companies licensed 26 Berkeley Lab technologies.

\section{E. Impact on the Nine- County Bay Area: Partnerships and Spin-offs}

Spin-offs, partnerships, and licensing deals based on patented Lab technologies help create jobs and have a positive effect on the country's economy. There have been 16 companies formed around licensed Berkeley Lab technologies since 1990 alone, accounting for at least 500 new jobs. These technologies include genomics-related software, materials sciences processing, biomolecular tagging, and energy efficiency home improvements. See the tables on the previous pages for a listing of our partnerships and spin-offs, and visit Tech Transfer's Web site for more information on these companies and organizations (http://www.lbl.gov/Tech-Transfer).

\section{F. The Bay Area Science Infrastructure Consortium (BASIC)}

Berkeley Lab actively participates in BASIC, a regional collaborative entity that ensures support for the region's research and development infrastructure and entrepreneurship through public education, advocacy, and by facilitating the movement of technologies from laboratories to the marketplace. The Lab recently partnered with BASIC in the production of the report, The Bay Area's Research Institutions: How an Extensive Research and Development Infrastructure Drives the Region's Innovative Economy. This report documents the critical link between the Bay Area's R\&D infrastructure and the economy and technical leadership of the region, state, and nation. 


\section{QUALITATIVE IMPACT}

W

Hile Berkeley Lab has a significant economic impact on Berkeley, the East Bay, and beyond, not every Berkeley Lab impact can be boiled down to dollars and cents. The Lab is also involved in a number of community outreach efforts.

\section{A. Education}

Berkeley Lab helps to prepare the next generation of scientists and engineers by contributing to the quality of mathematics, science, and technology education at all levels. To promote and ensure a coordinated Laboratory-wide education outreach effort and to build partnerships with schools and educators, the Center for Science and Engineering Education (CSEE) was established in 1988.
Over the last 12 years, thousands of local students have toured our world-renowned research facilities. Hundreds of laboratory staff members have volunteered in schools and special school-sponsored events. More than 200 school teachers and precollege students from Bay Area schools have worked under the mentorship of scientists during the summer, and many more have attended Laboratory-sponsored workshops. Stipends were given by the Laboratory through education grants. Up-to-date, highly valued science education materials produced at the Laboratory were provided to teachers and students free of charge.

In the summer of 2000 , 95 students and 45 teachers participated in education programs at Berkeley Lab.

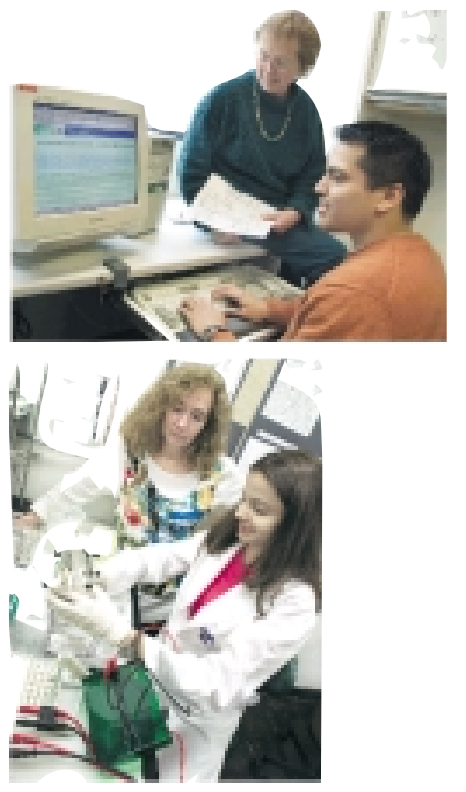

Berkeley Lab hosts students in the following programs:

Energy Research Undergraduate Laboratory Fellowship (ERULF). The U.S. Department of Energy's ERULF program is open to any undergraduate student who is a U.S. citizen or permanent resident, at least 18 years of age, and enrolled in an accredited U.S. college or university. It is for students in any scientific or engineering discipline.

\section{Community College Initiative in} Biotechnology, Environmental Science, and Computing (CCI). The Department of Energy's CCI program is open to students who are attending one of the California Community Colleges that are partnered with Berkeley Lab for this program.

\section{Pre-Service Teacher Program} (PST). This DOE program is designed to provide educational training and research experiences at DOE laboratories for a diverse group of highly motivated undergraduate students who are interested in becoming K-12 science, mathematics, and technology teachers.

\section{Integrated Science Partnership}

Project. This collaboration between Berkeley Lab and the Vallejo City Unified School District bridges the research conducted at the Lab with the standards-based science instruction given in the district's classrooms. The project helps the science teachers of the district to obtain resources for their curriculum development.

(For more information on Lab/education partnerships, visit the CSEE Web site at http://csee.lbl.gov/.) 


\section{B. Berkeley Lab Firefighters: Always on Call}

On July 9, 1999, smoke appeared in the hills above the UC Berkeley campus. The first firefighters to arrive were from the Berkeley Lab Fire Department. Shortly thereafter, City of Berkeley firefighters arrived. The response was so quick that the fire was held to one-quarter acre, with no buildings damaged.

This speedy effort was the first fruit of an automatic aid agreement between the City of Berkeley and Berkeley Lab fire departments, signed just three weeks earlier. According to this agreement, Berkeley Lab provides the first response to any call received from an area of Berkeley where Berkeley Lab firefighters would arrive fastest. This area includes most of the Berkeley hills, as well as areas near the UC campus.

Berkeley Lab's firefighters have been very active in supporting this automatic agreement: in the first ten months of 2000, Lab firefighters responded to over 400 calls.

\section{Berkeley Lab Volunteers}

Laboratory employees volunteer substantial amounts of time to activities that benefit the local community.

Just a few of the organizations are:

- Alameda County Economic Development Advisory Board

- Bay Area Defense Conversion Action Team

- Bay Area Science Infrastructure Consortium (BASIC)

- Bay Area Economic Forum

- Bay Area Regional Technology Alliance (BARTA)

- Berkeley Chamber of Commerce

- Berkeley Entrepreneur's Forum

- Berkeley Travel Reduction Program (TRIP)

- Chabot Space and Science Center

- Lawrence Hall of Science

- Oakland Metropolitan Chamber of Commerce

- The Society of Port Engineers
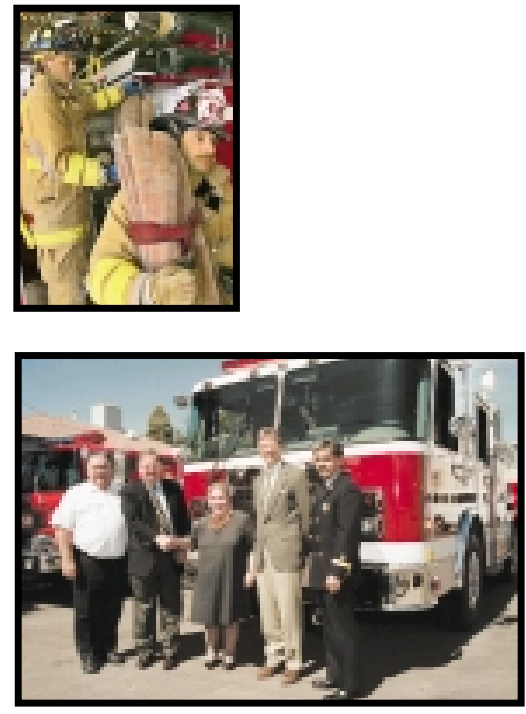

The key players in the fire aid agreement between Berkeley Lab and the City of Berkeley: Lab Fire Chief Stacy Cox, Director Charles Shank, Berkeley Mayor Shirley Dean, City Manager James Keen, and Berkeley City Fire Chief Reg Garcia.

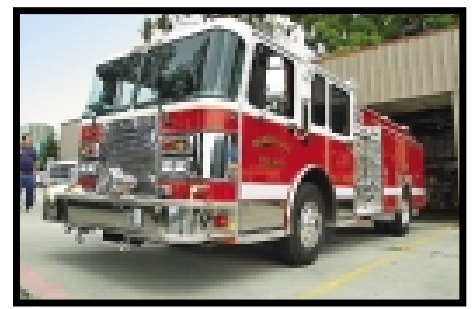




\section{WEB REFERENCES}

Ernest Orlando Lawrence Berkeley National Laboratory (http://www.lbl.gov)

The Advanced Light Source (http://www-als.lbl.gov/)

Biocompatible Contact Lenses (http://www.lbl.gov/Science-Articles/ResearchReview/Highlights/2000/stories/health/soft_touch.html)

The Berkeley Lamp (http://lighting.lbl.gov/projects/table/table.html)

The Berkeley Center for Structural Biology (http://www.lb.ogv/LBL/Programs/mcf)

Breast Cancer Research (http://www.lbl.gov/lifesciences/BissellLab/main.html)

The Center for Science and Engineering Education (http://csee.lbl.gov/)

National Center for Electron Microscopy (NCEM) (http://ncem.lbl.gov/ncem.html)

National Energy Research Scientific Computing Center (NERSC)

(http://www.nersc.gov/)

Ribosome Research (http://www.lbl.gov/Science-Articles/Research-

Review/Highlights/2000/stories/bioscience/ribosomal.html)

Spin-offs from Berkeley Lab (http://www.lbl.gov/Tech-Transfer/success_stories/ spinoffs/index.html)

Supernova SN 1997ff (http://www.lbl.gov/Computing-Sciences/Archive/ headlines04-02-01.html)

Technology Transfer Department (http://www.lbl.gov/Tech-Transfer)

UV Waterworks (http://eetd.lbl.gov/cbs/archive/uv/) 

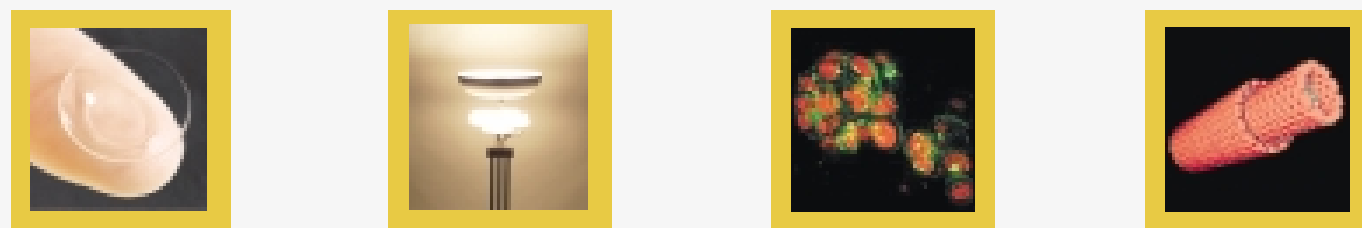

டBNL/PUB-854 